PUBLIPRENEUR POLIMEDIA: JURNAL ILMIAH JURUSAN PENERBITAN

POLITEKNIK NEGERI MEDIA KREATIF

Vol. 8, No. 2, December 2020 hal. 102-112

Submitted: 20 October 2020

Revised: 20 November 2020

Accepted: 20 December 2020

\title{
NEED ASSESSMENT OF DESIGNING MATERIALS FOR PUBLIPRENEUR BASED LANGUAGE LEARNING (PBLL)
}

\author{
Zalzulifa \\ Politeknik Negeri Media Kreatif \\ zalzulifa@polimedia.ac.id
}

\begin{abstract}
The research Need Assessment is necessary to make the decisions that influence a learner's progress. It should therefore be viewed as a fundamental practice that happens naturally in the teaching and learning process. This then means that learners should be assessed continuously to monitor their progress and make daily instructional decisions. The research background was done through the learning process at the State Polytechnic of Creative Media. In finding the right way of designing English material for the publishing students the researcher executed students' need assessment through questionnaire, interview and class observation (simulation) in learning process. The research question is overcome through eight items of respondents' understanding, namely: 1) Perception of Lecturers toward the publishing knowledge; 2) Institutional Awareness of Lecturer; 3) Students' role in learning activities; 4) lecturers' role in learning process; 5) Evaluation in learning process; 6) Difficulties in designing English materials; 7) Solution in problem solving; 8) Designing English material for the publishing students. The findings of this research cover three main points. First, in order to meet the publishing students' needs, the design of English learning materials should be formulated according to the level of competencies approaches to national qualification framework of Indonesia. Second, in order to meet the Industrial needs, the design of English learning materials must be able to promote students in performing various technical skills and publishing competencies needed for industry. Third, in order to improve students' proficiency in understanding EOP materials, the design of English learning materials can ellaborate Kathelen Graven's model with its modification by putting actualizing concept after conceptualizing contents.
\end{abstract}

Keyword: : Language Acquisition, publishing competencies, actualizing concepts, students' need

\section{BACKGROUND}

This research is back-worded by the pragmatic experiential learning problems the researcher faces in daily routine activities of teaching learning from first to fourth semester (2008-2011) at PoliMedia. It has accumulated into the researcher's pragmatic findings that teaching English for publishing students with its basic skills (reading, writing, listening, speaking) should be in line with the needed basic competencies of language assessment in the publishing needed skills (pre-writing, drafting, revising, editing, and publishing). However, in order to assure the pragmatic findings it is needed to do the academic analysis through the following academic research methodology, including: setting and time, research design, population and sample, data collection instrument, and data analysis.

The research result is expected to provide PoliMedia with the right model of designing English language learning material used for guiding the students and lecturer hand-in-hand in the learning process. The most significant of the research is based on what the PoliMedia's function to steerup the three years diploma program 
focussed on the need for publishing students as supposed intellectual resources of national Publishing Industry in Indonesia.

\section{DISCUSSION}

For assuring the industrial needs and for the acomplishment of the data in this session the researcher provides the information of industrial need taken from eight subheadings to answer the research questions "How does the English Materials meet the Industry needs?" Those subheadings consist of: 1) Perception of Lecturers toward the publishing knowledge; 2) Institutional Awareness of Lecturer; 3) Students' role in learning activities; 4) lecturers' role in learning process; 5) Evaluation in learning process; 6) Difficulties in designing english materials; 7) Solution in problem solving; 8) Desigining english material for the

publishing students. The data to answer the eight subheadings were taken from the questionaire, interviews and classroom observation.

Lecturer's Perception on the Publishing Knowledge.

Concerning with lecturers' perception about the publishing knowledge, data from interview shows that they have good understanding about the publishing know-how. The respondents' perception can be seen in the tabulation of interview category of the answer to the questionnaire. All respondents have a strong understanding that language is the most important factor in publishing activities. They agree that publishing becomes a business that is closely linkage to the communication
R\#4

\begin{tabular}{|c|c|}
\hline Question & The publishing \\
\hline Answer & $\begin{array}{l}\text { knowledge is part } \\
\text { of communication } \\
\text { based } \\
\text { intellectual } \\
\text { resources. Explain } \\
\text { how far do know } \\
\text { about this } \\
\text { statement? }\end{array}$ \\
\hline R\#1 & $\begin{array}{lr}\text { I agree, Publishing } \\
\text { science used for } \\
\text { communicating by } \\
\text { printing } \\
\text { visualization } \\
\text { alphabet with } \\
\text { picture. }\end{array}$ \\
\hline R\#2 & $\begin{array}{l}\text { Publising is the } \\
\text { science and become } \\
\text { one of media or } \\
\text { communication } \\
\text { tools }\end{array}$ \\
\hline
\end{tabular}

Agree, because media of publishing products is writing as the language of communication, while the core point of communication is the knowledge itself Yes, the science of publishing is part of communication,

language and economy

R\#5 The science of publishing is the knowledge based on idea. It means, by having the knowledge of publishing one must be able to produce and to manage idea and to sell as well. 
Henceforth the respondents realize language as the main resource based capital for building the publishing business either Indonesia language as the first or English as an international language. Language skills are competency needed by the writer or editor in oder to convey the message clearly.

\section{Questioner 2}

Question

Answer

R\#2

R\#3

\section{The language competencies in publishing is mainly required within the competencies of publishing industry. Explain your understanding? are competency that needed to the writer or editor so the massages convey clearly.}

R\#1 Yes, language skills

Agree, because in publishing particularly the work of editor cannot be far away from the language role especially the good and right national language of Indonesia and English as the international one.

Absolutely agree, because language is the mayor capital within the world of publishing, hence the language competencies

\begin{tabular}{ll}
\hline & become dominant \\
factor in producing \\
good publishing \\
products. \\
Language is the key \\
factor to deliver \\
message, so \\
language is \\
important \\
publishing \\
Language is the \\
mayor factor in the \\
knowledge of \\
publishing because \\
through language \\
one can produce \\
various creative \\
products. On the \\
other hand, \\
language is the \\
system that is also \\
becoming tools for \\
developing creative \\
idea to be published.
\end{tabular}

Furthermore, respondents also show their understanding about. the language acquisition in basic skills (reading, writing, listening, speaking) is required within the production cycle of publishing industry ranging from prewriting-drafting-revising-editingpublishing

\section{Questioner 3}

Question The language

Answer acquisition in basic skills (reading, writing, listening, speaking) is required within the production cycle of publishing industry ranging from prewritingdrafting-revising- 


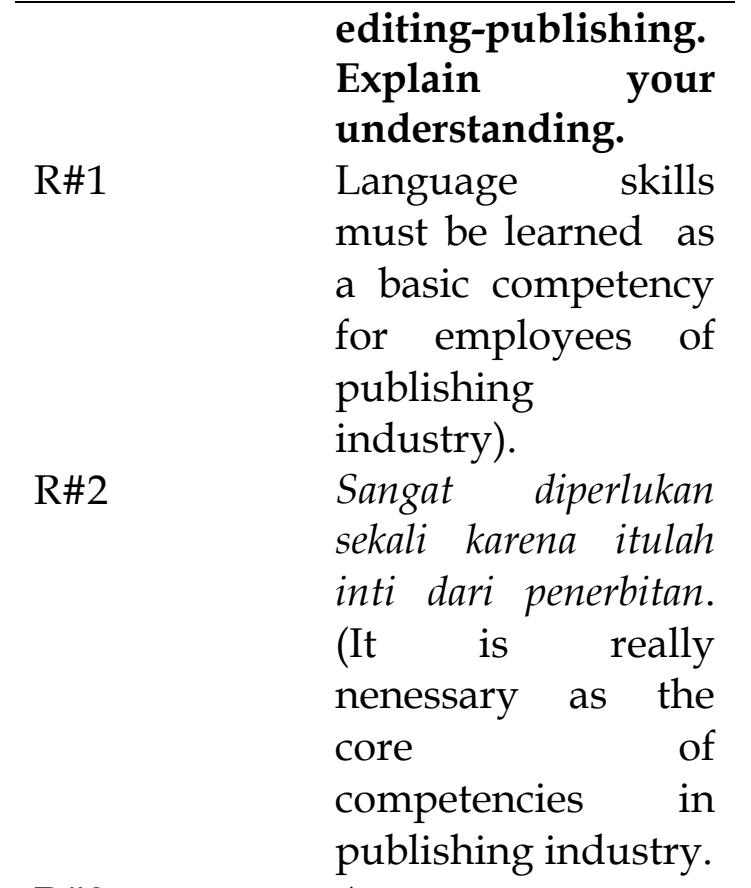

R\#3

R\#4

R\#5
Agree

One will be able to write well when they get good input. This means that the skills from reading, writing, listening and speaking are interrelated each others.

It is agreed that the effective way of acquiring language competencies

through hand-on practice, so the education process should also be based on competencies. The essential language

competencies consist of reading, writing, listening and speaking. In the context of publishing industry that mostly produce the written
products, the steps of prewriting- drafting-revising- editing-publishing become the essential system in developing world of publishing.

From the questionare above, it was found that the respondents agree the main competencies of language (reading, writing, speaking, listening) and it approved that the publishing knowledge is part of human creativity that continually develop from time to time in accordance with the development of civilization and its required modern era. This is also the consequence of the human being as the creature that each communicates and interacts one among others.

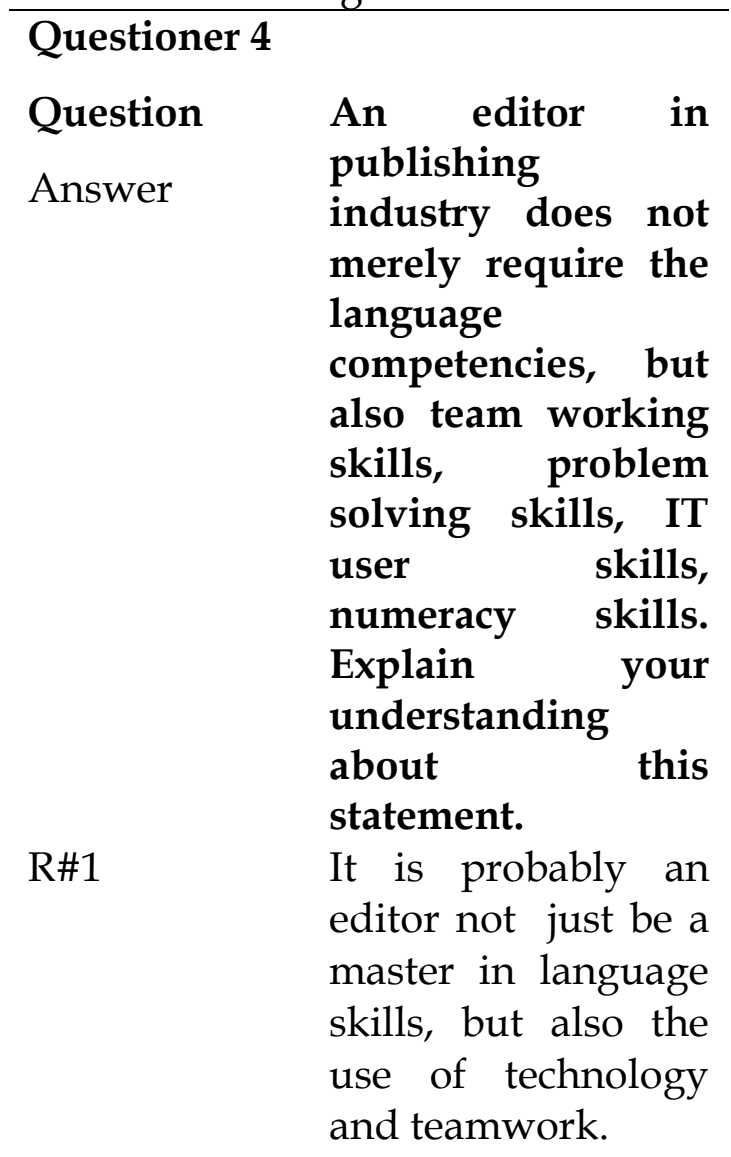




\begin{tabular}{ll}
\hline R\#2 & Absolutely agree. \\
& The success of every \\
& one $80 \%$ depending \\
& on how they are \\
& communicating \\
& with, negotiating \\
& with, networking, \\
& teamwork, \\
& technology user and \\
& alike. \\
& Absolutely agree, an \\
& editor also should be \\
& master in \\
R\#3 & manuscript \\
& contents. \\
& Ya, because they are \\
& not only as \\
intellectual resource \\
based but also the \\
producer in a \\
publishing business. \\
Absolutely agree. \\
All must be \\
holistically \\
integrated within \\
one's competencies \\
of an editor.. \\
R\#5
\end{tabular}

In addition to language competencies, the data indicates that the performance of a language worker in publishing industry called "editors" not only require language competencies but also the need to empower the pesonal talent of teamworking skill, problem solving skills and technology user skills. This can be a pragmatic findings of English urgency when once there is an event of colaboration with those who come from abroad in which English is the only communication tools or perhaps the incoming printing technology with six manual languages and one of them is English.

\section{Questioner 5}

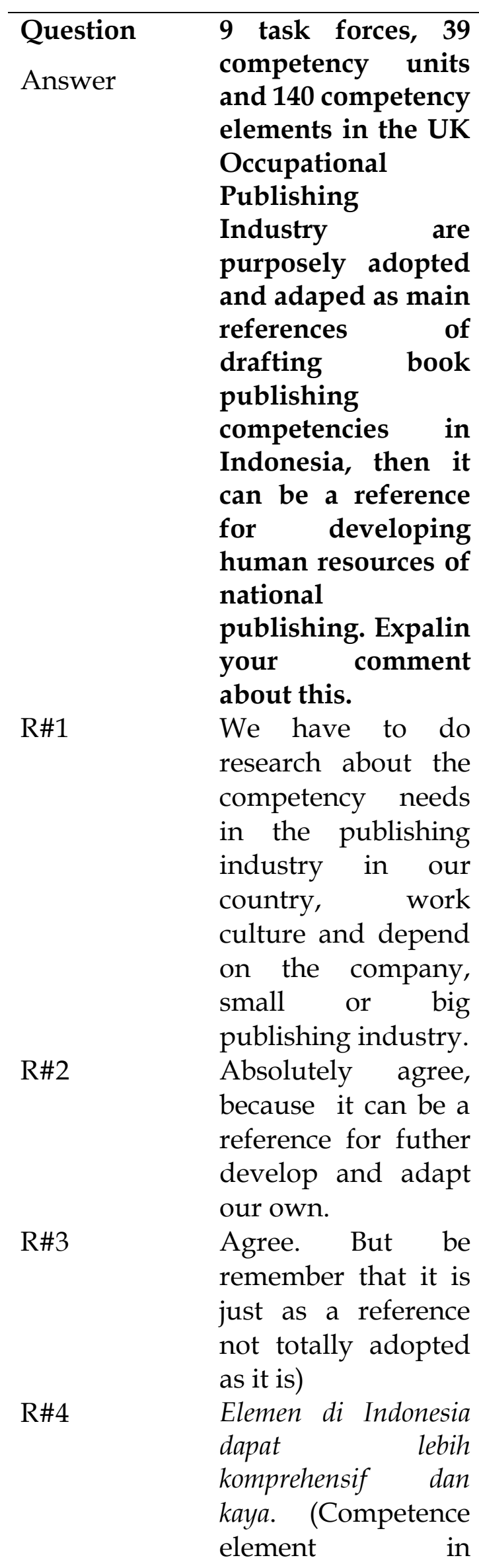




\begin{tabular}{ll}
\hline & Indonesia can be \\
& comprehensively \\
various and rich. & I think it can be used \\
R\#5 hence & implemented into \\
& our currciculum \\
& innovative and \\
& accurately.
\end{tabular}

In the questionaer 5 above, respondents approve the process of adopting and adapting UK competencies standard in the language course design. ISP. Nation and John Macalister pp.11 in "Language Curriculum Design" underlines the important of having a flexible approach to the use of a course book and of choosing a course book which allows for flexibility"1. A head of national council UK, John Whitley in his email letter recommended researcher for copyright unbreaking to translate and adapt UK National Occupational in Publishing Industry ${ }^{2}$

It shows that mayority respondents are fully kanowlegable about the publishing know-how. The $73.91 \%$ respondents show their majority agreement on responding five statements by its supports with each statement's ranks delivered in the following table:

All the previous interviews about perception in publishing knowledge were delivered to the respondents and data from quetioner reveals that $73,91 \%$ respondents agree, $24,35 \%$ absolutely agree, and $1,74 \%$ disagree. This data can be assumed that most respondents already know and quite familiar with the publishing knowledge. They know

\footnotetext{
${ }^{1}$ I.S.P.Nation John Macalister; Language Currciculum Design. Routledge Taylor \& Francis Group New York and London.pp.11,
}

already that publishing is a part of communication and most related with the business aspect. So, in the the context of reliable information the perception of respondents can reflect that data is acceptable.

\section{Respondents' awareness on the institutional policy. \\ Data interview shows that all respondents agree with the policy of production and entrepreneurship based curriculum development at PoliMedia. Event, they requested to do furtherly development and continually improvement toward the adaptive curriculum and learning materials approach to the industrial needs.}

\section{Questioner 1}

Question The policy of

Answer curriculum and material development based on production and enterpreneurship approach is already on the track for an education institution diplom 3 like PoliMedia. Give your comment about this.

R\#1 That right, but the content of curriculum can not applied cause it has not be supported by the human resources.

R\#2 Absolutely agree, but still need to

\footnotetext{
2 Jhon Whitley (UK National Standard Council); email letter to please the researcher adapting UK Occupational Standard in Publishing Industry 2011
} 


\begin{tabular}{ll}
\hline & reconceptualize \\
about the meaning \\
of production and \\
entrepreneurship. \\
It is already on the \\
tract. But based on \\
the existing \\
condition, the policy \\
is still not strongly \\
bounded to all \\
academc societies of \\
PoliMedia. It needs \\
control and \\
evaluation from \\
time to time until it \\
suits to be \\
implemented. \\
Agree, but there are \\
some things not \\
applicable like \\
classification of \\
subjects which are \\
not in balance yet. \\
I think it is already \\
on the track \\
approaches to the \\
vocational \\
education system to \\
produce \\
students ready to \\
work and business.
\end{tabular}

Nevertheless, from the interview the data shows that the needs for quality assurance of publishing graduates strongly recommended in order the comparative learning hours theory and practice $(60 \%: 40 \%)$ can produce the students' output with strong talent in creating job opportunity $(80 \%)$ or doing enterpreneuship in the field of publishing $(20 \%)$ both private or government.

\section{Questioner 2}

Question

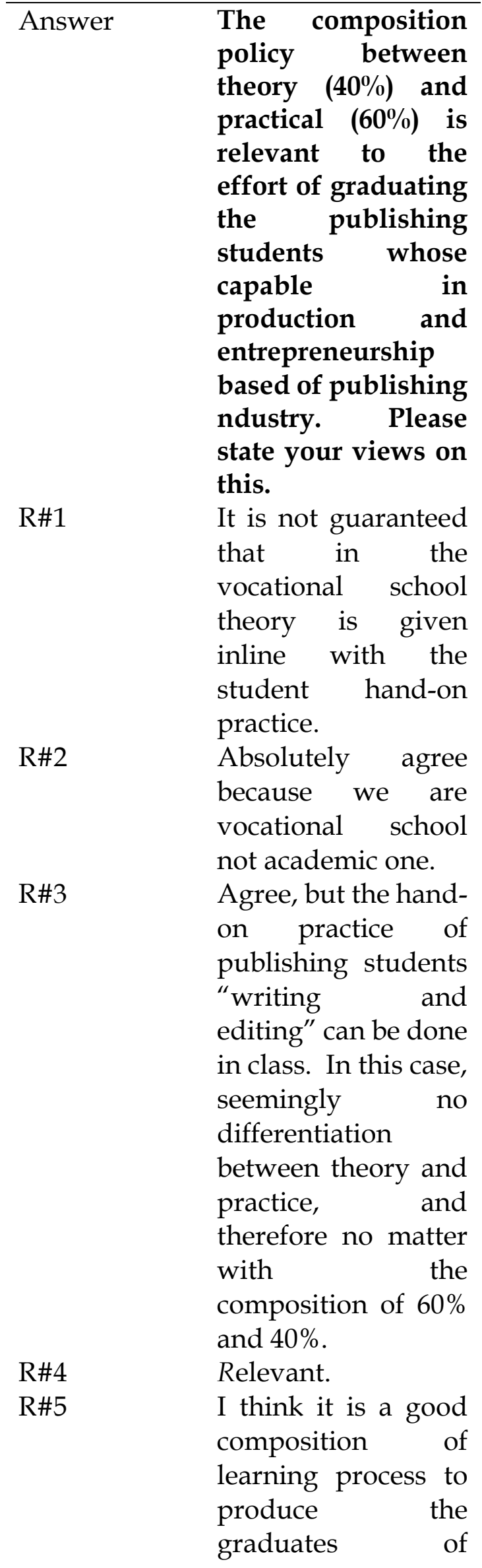




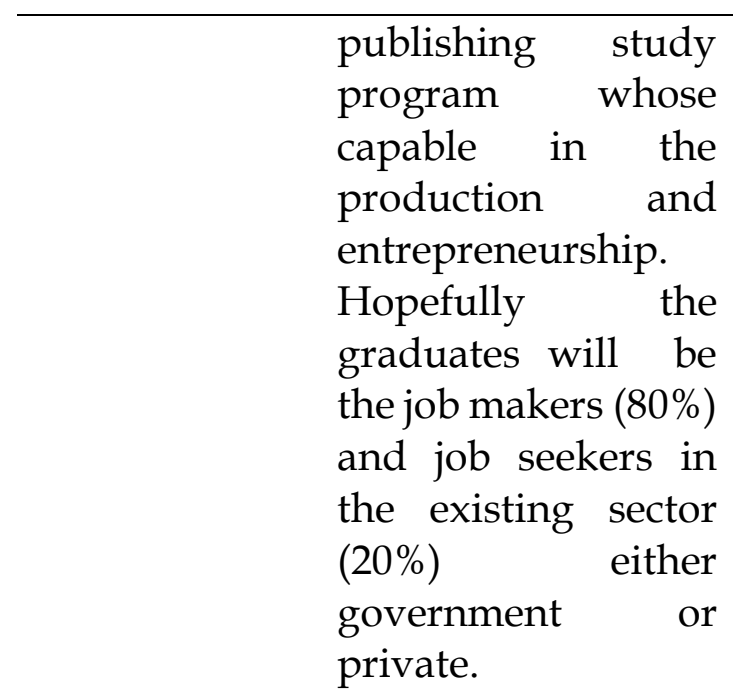

In order to support the implementation of institutional policy especially dealing with the vocational learning strategy, respondents also recommended PoliMedia to have a good relationship and cooperation in building mutual understanding of link and match with relevant association like Indonesia Book Publisher (Ikatan Penerbit IndonesiaIKAPI) and Newpaper Publisher Association (Serikat Penerbit Surat Kabar - SPS). The collobaration between PoliMedia and related partners will strengthen the implementation of internal policy by which mutual communication between educational institution and stakeholder or industry will flow smoothly.

\section{Questioner}

3

\begin{tabular}{|c|c|}
\hline Question & PoliMedia needs to \\
\hline Answer & build a synergy \\
\hline HIISW & collaboration with \\
\hline & related association \\
\hline & $\begin{array}{lr}\text { of } & \text { publishing } \\
\text { industry, } & \text { like }\end{array}$ \\
\hline & Indonesia \\
\hline & Publishers \\
\hline & Association \\
\hline & Indonesia \\
\hline
\end{tabular}

\begin{tabular}{|c|c|}
\hline & $\begin{array}{l}\text { Publishing } \\
\text { Association. Please } \\
\text { mention a good } \\
\text { strategy to build a } \\
\text { partnership } \\
\text { mutual with } \\
\text { between education } \\
\text { and industry. }\end{array}$ \\
\hline \multirow[t]{2}{*}{ R\#1 } & $\begin{array}{l}\text { Not only association } \\
\text { in publishing but } \\
\text { PoliMedia needs to } \\
\text { make an agreement } \\
\text { with Ministry of }\end{array}$ \\
\hline & $\begin{array}{l}\text { Manpower, } \\
\text { and chamber } \\
\text { Industry as well as } \\
\text { another training } \\
\text { organization. }\end{array}$ \\
\hline R\#2 & $\begin{array}{l}\text { Having mutual } \\
\text { communication }\end{array}$ \\
\hline & $\begin{array}{l}\text { continuously and } \\
\text { beneficial } \\
\text { collaboration in every } \\
\text { activities. }\end{array}$ \\
\hline R\#3 & $\begin{array}{l}\text { Absolutely agree, Of } \\
\text { course the } \\
\text { collaboration should } \\
\text { be mutual benefit } \\
\text { There should be a } \\
\text { collaboration for } \\
\text { requirement and } \\
\text { placement as well as } \\
\text { continually } \\
\text { improvement of the } \\
\text { graduate quality. }\end{array}$ \\
\hline R\#4 & $\begin{array}{l}\text { There are lots of } \\
\text { benefit, especially for } \\
\text { the development of } \\
\text { student both } \\
\text { academic and non- } \\
\text { academics. }\end{array}$ \\
\hline R\#5 & $\begin{array}{l}\text { I think there should } \\
\text { be synergy with well- } \\
\text { planned programs } \\
\text { through }\end{array}$ \\
\hline
\end{tabular}

mention a good strategy to build a partnership with mutual benefit between education and industry. in publishing but PoliMedia needs to mike an agreement with Ministry of Manpower, Trade and chamber Industry as well as another training organization.

communication continuously and beneficial collaboration in every activities. course the collaboration should be mutual benefit . There should be a collaboration requirement and placement as well as continually improvement of the graduate quality. benefit, especially for development of student academic and nonacademics. be synergy with wellplanned programs involvement of all 


stakeholders. On the
other hand, the
education institution
ought to understand
the needs of
publishing industry
as represented by
IKAPI and SPS.

When asking the respondents about their view on the efforts of adopting and adapting national occupational standard in publishing industry United Kingdom, they give their support and think that it is a good starting point especially in initiating the establisment of international publishing study program at PoliMedia. Nevertheless, in some cases one ought to realize that the developed country is more competitive in publishing knowledge. Of course it is costly to do benchmarking but the outcome will be more valuable for the changing of mindset both internal resources of PoliMedia and publishing practiotioners in general.

$\begin{array}{ll}\text { Questioner } & \\ \text { Question } & \begin{array}{l}\text { The iniciative for } \\ \text { adoption } \\ \text { adaptation of UK } \\ \text { Publishing }\end{array} \\ & \begin{array}{l}\text { Occupational } \\ \text { Standard is the right } \\ \text { moment to establish } \\ \text { the } \\ \text { publishing world-class }\end{array} \\ & \begin{array}{l}\text { program. Give your } \\ \text { comment about this). }\end{array} \\ & \begin{array}{l}\text { Of course, it can be } \\ \text { reference to make a } \\ \text { curriculum } \\ \text { learning material for } \\ \text { international } \\ \text { publishing class. }\end{array}\end{array}$

\begin{tabular}{|c|c|}
\hline R\#2 & $\begin{array}{l}\text { Absolutely agree, we } \\
\text { can adapt the UK } \\
\text { competency standar in } \\
\text { accordance to our } \\
\text { original culture }\end{array}$ \\
\hline R\#3 & $\begin{array}{l}\text { Agree, as long as not } \\
\text { plagiarism. }\end{array}$ \\
\hline R\#4 & $\begin{array}{l}\text { Yes, it must be adjusted } \\
\text { to the Indonesia } \\
\text { context. However, it is } \\
\text { needed to have study } \\
\text { visit nevertheless it is } \\
\text { costly but it is a must } \\
\text { and good for shifting } \\
\text { mindset of lecturers or } \\
\text { publishing } \\
\text { practitioners. }\end{array}$ \\
\hline R\#5 & $\begin{array}{l}\text { Absolutely agree, the } \\
\text { most important thing is } \\
\text { creating Indonesia } \\
\text { standar of publishing } \\
\text { competence } \\
\text { approaches to our own } \\
\text { culture. The adaptation } \\
\text { process is expectedly } \\
\text { produce the new } \\
\text { models and it must be } \\
\text { better than the original } \\
\text { one. }\end{array}$ \\
\hline
\end{tabular}

The greatest expectation of stakeholders towards the graduates' quality of publsihing study program has intentionally requested the respondents to support Polimedia in designing all learning materials including "English for Publishing" approached to the national occupational standard of publishing industry. The respondents suggest PoliMedia to invite the publishing practitioners in one pannel discussion in order to find a good formula of link and match as the way to assure the highest graduate acceptability. 


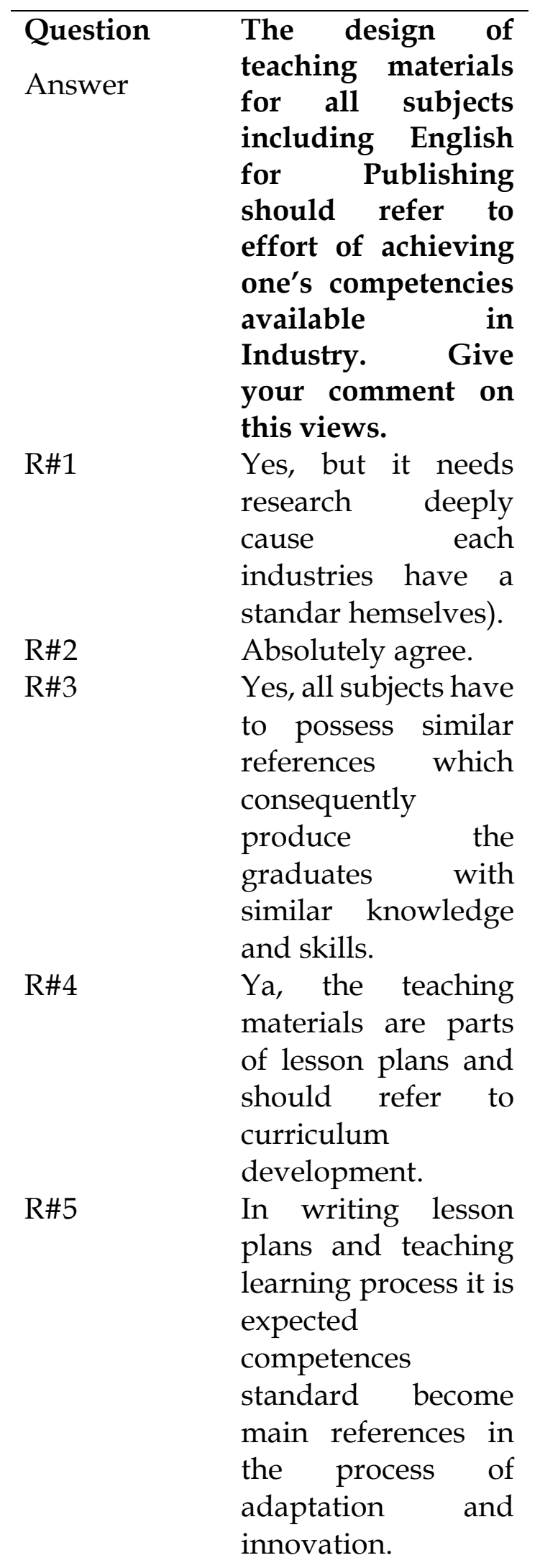

All the previous interviews about respondents' awareness on the institutional policy were delivered to the respondents and data from quetioner reveals that $83,04 \%$ respondents agree, $13,48 \%$ absolutely agree and 3,48\% disagree. This data can be assumed that most respondents already aware and receive the policy within the education constrain. The production and entrepreneurship based curriculum and learning strategy is the way to make students not only capabale in making goods but also in selling as well.

It shows that mayority respondents are fully knowlegable about the institutional policy of PoliMedia "Production and Entrepreneurship Based Curriculum and Learning Strategy". The $83.04 \%$ respondents show their agreement on responding five statements by its supports with each statement's ranks

\section{REFERENCES}

Alderson, L.C. Material Evaluation in Harper, D.P.L. (ed.) English For Specific Purpose, papers from the 2nd Latin American Regional Conference Cocoyoc, 25-30 March 1997.

Allwright, R.L. What do we want teaching materials for? In Rossner and R. Bolitho (Eds.), Current In Language Teaching. Oxford University Press, 1990.

Alderson Charles and Bachman F Lyle. Assessing Writing. United Kingdom: Cambridge University Press, $6^{\text {th }}$ edition, 2009.

Allison Baverstick. How to Market Books, , $4^{\text {th }}$ Edition Hogan Page, 2008.

Basturkmen Helen. Developing Courses in English for Specific Purposes. New York: Palgrave Macmillan, 2010.

Benyamin S. Bloom, Bertram B., Mesia and David R. Krathwohl. Taxonomy of Educational Objectives. New York : David Mckay, 1964.

Brown, J.D. The Element of Language Curriculum: A systematic Approach To Program 
To program Development. Heinle \& Heinl, 1995.

Campbell Linda, Cambell Bruce, and Dickinson Dee.Teaching and Learning through Multiple Intelligences. United State of America: A Simon \& Schster Company, 1996.

Chen, Y. Material Production for Architecs and Civil Enginers, 2008.

Crawford J. The Role of Materials In The

Language Classroom: Finding the Balance, 2002. 